\title{
THE EFFECT OF CARBON DIOXIDE ON THE PULMONARY CIRCULATION *
}

\author{
By F. MANFREDI $\dagger$ AND H. O. SIEKER \\ (From the Department of Medicine, Duke University School of Medicine, \\ Durham, N.C.)
}

(Submitted for publication July 27, 1959; accepted September 18, 1959)

At present there is experimental and clinical evidence to support the view that alteration in alveolar oxygen tension has a direct effect on pulmonary circulation. Animal experimentation (1-4) and hemodynamic studies in human subjects (5-8) indicate that pulmonary vascular resistance increases and blood flow is thereby reduced in hypoxic areas of the lung. This is apparently a mechanism by which the body decreases perfusion of poorly ventilated lung and thus maintains efficient respiration.

The effect of changes in alveolar carbon dioxide tension on pulmonary hemodynamics is less well understood. Von Euler and Liljestrand (1) showed in cats that pulmonary hypertension ensued when the concentration of carbon dioxide in the inspired air was increased to 6.5 per cent. Variable responses of the pulmonary vascular dynamics have been reported by Nisell $(9,10)$, who studied the effect of carbon dioxide on the isolated cat lung. Stroud and Rahn (11) reported that pulmonary vascular resistance did not change when animals were ventilated with mixtures containing 5 per cent carbon dioxide. Weil, Salisbury and State (12), in an open chest dog preparation, observed that carbon dioxide can cause pulmonary vasomotion. Borst, Whittenberger, Berglund and McGregor (13), using dogs, found a redistribution of blood away from the lung ventilated with 5 per cent carbon dioxide and air mixture and concluded that local vasoconstriction occurred. In 20 patients with congenital heart disease, Shephard (14) found that 5 per cent carbon dioxide given during catheterization produced moderate but consistent degrees of pulmonary hypertension.

* Supported in part by grants from the United States Public Health Service (Grant A-1596), the North Carolina Heart Association, and the Life Insurance Medical Research Fund.

$\dagger$ Research Fellow of the American Heart Association, 1958-1959.
This was attributed to an increase of the total pulmonary vascular resistance as well as to a moderate increase in cardiac output and possibly also to an elevation of the pressure gradient across the lungs. On the other hand, Peters (15) observed that an increase in alveolar carbon dioxide tension in the dog lung, isolated by bronchospirometric technique, was followed by an increase in oxygen consumption and presumably by a decrease in vascular resistance and an increase in blood flow through that lung.

This study was designed to investigate the effects of carbon dioxide on the pulmonary vascular bed and its mechanism of action. Preliminary experiments, carried out in this laboratory on intact anesthetized dogs, suggested that inhalation of air containing a high concentration of carbon dioxide may alter the dynamics of the lesser circulation. Several factors were identified or suspected to be "indirectly" responsible for these changes, i.e., stimulation of the respiratory center with variations of transpulmonary resistance, modification of airway resistance, and alteration of systemic circulatory hemodynamics. To evaluate the possibility of a "direct" effect of carbon dioxide on the pulmonary vascular bed, all these factors should be eliminated or controlled. This report describes the effect of carbon dioxide on the circulation of the isolated lung lobe.

\section{METHODS}

In 15 healthy medium size dogs the left lower lobe was exposed, ventilated, and perfused under controlled conditions as shown in Figure 1. A Bird respirator was connected by a large plastic tube to the left lower lobe main bronchus in order that this lobe could be ventilated independently of the remaining lung. Intermittent positive pressure not exceeding $25 \mathrm{~mm} \mathrm{Hg}$ was used, and ventilation was kept constant throughout the experiment. A similar respirator connected with an endotracheal cannula ventilated the remaining parts of the lungs with normal minute volume for the animal. The pulmonary 


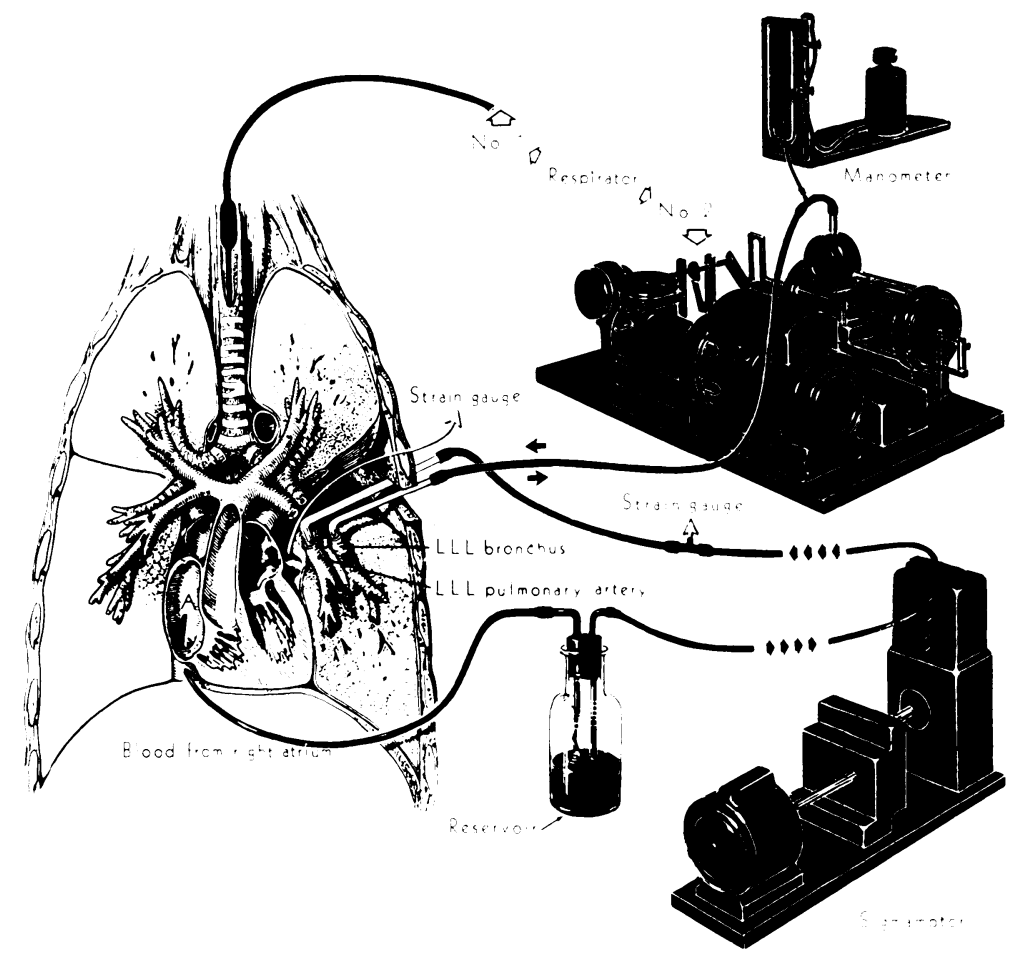

lig. 1. Scheme of experimental preparation. I.l. = left lower lobe.

artery to the left lower lobe was perfused with a Sigmamotor pump under constant flow, using venous blood obtained from the right atrium and collected into a reservoir. The remainder of the lung was perfused in normal fashion by the right ventricle.

Pressures were recorded continuously from the pulmonary artery and pulmonary vein of the isolated lobe. Pulmonary vascular resistance was calculated from the pressure gradient and the controlled flow rate and expressed as millimeters of mercury per cubic milliliter per minute. Positive pressure in the left lower lobe main bronchus was continuously monitored by a mercury manometer connected to the plastic cannula. Blood samples were obtained from the left lower lobe pulmonary artery and vein during phases of the experiment for gas and $\mathrm{pH}$ determinations. Blood oxygen content and saturation were measured by the photometric method of Hickam and Frayser (16). Blood carbon dioxide was determined by the method of Peters and Van Slyke (17). The $\mathrm{pH}$ of whole blood was measured with a Cambridge Model $\mathrm{R}$ pH meter with enclosed glass electrode; measurements were corrected to $37^{\circ} \mathrm{C}$, using Rosenthal's factor (18). Plasma carbon dioxide content was calculated from the blood carbon dioxide content, $\mathrm{pH}$, and hemoglobin, using the line chart of Van Slyke and Sendroy (19). Carbon dioxide tension was calculated from this value, using the Henderson-Hasselbalch equation. All determinations were done in duplicate. Venous $\mathrm{pCO}_{2}$ was taken to represent alveolar $\mathrm{pCO}_{\text {. }}$.

This technique allowed the elimination or control of all factors that may indirectly interfere with perfusion of blood through the lungs, such as cardiac output, left auricular pressure, airway resistance, and transthoracic pressure. It also permitted the oxygen and carbon dioxide tension to be varied as desired in the alveoli and pulmonary veins of the explored lobe by ventilating this lobe with various gas mixtures. Oxygen and carbon dioxide tension were also varied in the blood perfusing the isolated lobe by adjusting the rate of ventilation and/ or changing the respiratory gas administered to the remaining parts of lung.

\section{RESULTS}

The results of the study are summarized in Table $I$. In nine animals, the administration of 5 per cent and 10 per cent carbon dioxide in 20 per cent oxygen and nitrogen mixture to the explored lobe resulted in an increase in the alveolar and pulmonary renous carbon dioxide tension within one minute. No change was observed in the endobronchial or pulmonary venous pressures. The mean pulmonary artery pressure of the isolated lobe increased, however, from a mean for the group of 21 to $27 \mathrm{~mm} \mathrm{Hg}$. Since the blood flow was constant, the calculated pulmonary vascular resistance increased significantly in each case (Figure 2). The mean for the group changed from $0.20 \mathrm{to} 0.29 \mathrm{~mm} \mathrm{Hg}$ per $\mathrm{ml}$ per minute. 
With the resumption of air breathing, alveolar and lungs (Table I). This produced a marked elevavenous carbon dioxide tension, pulmonary artery pressure, and pulmonary vascular resistance returned toward control values.

In four animals, carbon dioxide was subsequently administered to the remaining parts of the tion of the carbon dioxide tension in the systemic blood ( $\mathrm{pCO}_{2}$ up to $82 \mathrm{~mm} \mathrm{Hg}$ ) and therefore in the blood perfusing the artery and vein of the left lower lobe, as well as in the alveoli of the same lobe. However, no significant change of the cal-

TABLE I

Effect of carbon dioxide on pulmonary circulation

\begin{tabular}{|c|c|c|c|c|c|c|c|c|c|c|}
\hline \multirow[b]{2}{*}{$\begin{array}{l}\text { Exp. } \\
\text { no. }\end{array}$} & \multirow{2}{*}{$\frac{\begin{array}{c}\text { Remaining } \\
\text { lung }\end{array}}{\begin{array}{c}\text { Gas } \\
(\text { respirator } \\
n o .1)\end{array}}$} & \multicolumn{9}{|c|}{ Left lower lobe } \\
\hline & & $\begin{array}{c}\text { Gas } \\
\text { (respirator } \\
n 0.2)\end{array}$ & $\begin{array}{c}\text { Blood } \\
\text { flow }\end{array}$ & $\begin{array}{c}\text { Mean } \\
\text { PA** } \\
\text { pressure }\end{array}$ & $\begin{array}{c}\text { Mean } \\
\text { pV* } \\
\text { pressure }\end{array}$ & $\begin{array}{c}\text { Calculated } \\
\text { vascular } \\
\text { resistance }\end{array}$ & $\mathrm{PA} \mathrm{pH}$ & $\mathrm{PV} \mathrm{pH}$ & $\mathrm{PA} \mathrm{pCO}_{2}$ & $\mathrm{PV} \mathrm{pCO}_{2}$ \\
\hline & & & $\mathrm{ml} / \mathrm{min}$ & $m m \mathrm{Hg}$ & $m m H g$ & $\underset{m l / m i n}{m m H g l}$ & & & & \\
\hline 1 & $\begin{array}{l}\text { air } \\
\text { air } \\
\text { air }\end{array}$ & $\begin{array}{l}\text { air } \\
10 \% \mathrm{CO}_{2} \\
\text { air }\end{array}$ & $\begin{array}{l}60 \\
60 \\
60\end{array}$ & $\begin{array}{l}12 \\
20 \\
12\end{array}$ & $\begin{array}{l}4 \\
4 \\
4\end{array}$ & $\begin{array}{l}0.13 \\
0.26 \\
0.13\end{array}$ & & & & $\begin{array}{l}12.21 \\
27.07\end{array}$ \\
\hline 2 & $\begin{array}{l}\text { air } \\
\text { air } \\
\text { air }\end{array}$ & $\begin{array}{l}\text { air } \\
10 \% \mathrm{CO}_{2} \\
\text { air }\end{array}$ & $\begin{array}{l}100 \\
100 \\
100\end{array}$ & $\begin{array}{l}15 \\
19 \\
15\end{array}$ & $\begin{array}{l}3 \\
3 \\
3\end{array}$ & $\begin{array}{l}0.12 \\
0.16 \\
0.12\end{array}$ & & & & $\begin{array}{l}10.10 \\
23.13\end{array}$ \\
\hline 3 & $\begin{array}{l}\text { air } \\
\text { air } \\
\text { air }\end{array}$ & $\begin{array}{l}\text { air } \\
10 \% \mathrm{CO}_{2} \\
\text { air }\end{array}$ & $\begin{array}{l}45 \\
45 \\
45\end{array}$ & $\begin{array}{l}14 \\
20 \\
15\end{array}$ & $\begin{array}{l}3 \\
3 \\
3\end{array}$ & $\begin{array}{l}0.24 \\
0.37 \\
0.26\end{array}$ & $\begin{array}{l}7.51 \\
7.51 \\
7.49\end{array}$ & & $\begin{array}{l}37.91 \\
40.68 \\
37.66\end{array}$ & $\begin{array}{l}10.88 \\
27.28\end{array}$ \\
\hline 4 & $\begin{array}{l}\text { air } \\
\text { air } \\
\text { air }\end{array}$ & $\begin{array}{l}\text { air } \\
10 \% \mathrm{CO}_{2} \\
\text { air }\end{array}$ & $\begin{array}{l}60 \\
60 \\
60\end{array}$ & $\begin{array}{l}15 \\
20 \\
15\end{array}$ & $\begin{array}{l}5 \\
5 \\
5\end{array}$ & $\begin{array}{l}0.16 \\
0.25 \\
0.16\end{array}$ & $\begin{array}{l}7.19 \\
7.13 \\
7.06\end{array}$ & $\begin{array}{l}7.32 \\
7.03 \\
7.18\end{array}$ & $\begin{array}{l}31.03 \\
30.81 \\
37.28\end{array}$ & $\begin{array}{l}10.84 \\
28.07 \\
14.09\end{array}$ \\
\hline 5 & $\begin{array}{l}\text { air } \\
\text { air } \\
\text { air }\end{array}$ & $\begin{array}{l}\text { air } \\
5 \% \mathrm{CO}_{2} \\
\text { air }\end{array}$ & $\begin{array}{l}100 \\
100 \\
100\end{array}$ & $\begin{array}{l}15 \\
21 \\
16\end{array}$ & $\begin{array}{l}5 \\
5 \\
5\end{array}$ & $\begin{array}{l}0.10 \\
0.16 \\
0.11\end{array}$ & $\begin{array}{l}7.32 \\
7.34\end{array}$ & $\begin{array}{l}7.13 \\
7.14\end{array}$ & $\begin{array}{l}21.02 \\
27.01\end{array}$ & $\begin{array}{l}17.02 \\
26.78\end{array}$ \\
\hline $6 a$ & $\begin{array}{l}\text { air } \\
\text { air } \\
\text { air }\end{array}$ & $\begin{array}{l}\text { air } \\
10 \% \mathrm{CO}_{2} \\
\text { air }\end{array}$ & $\begin{array}{l}120 \\
120 \\
120\end{array}$ & $\begin{array}{l}45 \\
52 \\
44\end{array}$ & $\begin{array}{l}6 \\
7 \\
7\end{array}$ & $\begin{array}{l}0.32 \\
0.37 \\
0.30\end{array}$ & $\begin{array}{l}7.30 \\
7.26 \\
7.17\end{array}$ & $\begin{array}{l}7.41 \\
7.17 \\
7.35\end{array}$ & $\begin{array}{l}45.03 \\
48.72 \\
56.31\end{array}$ & $\begin{array}{l}27.09 \\
52.12 \\
27.00\end{array}$ \\
\hline $6 \mathrm{~b}$ & $\begin{array}{l}\text { air } \\
10 \% \mathrm{CO}_{2} \\
\text { air }\end{array}$ & $\begin{array}{l}\text { air } \\
\text { air } \\
\text { air }\end{array}$ & $\begin{array}{l}120 \\
120 \\
120\end{array}$ & $\begin{array}{l}45 \\
45 \\
45\end{array}$ & $\begin{array}{l}7 \\
7 \\
7\end{array}$ & $\begin{array}{l}0.31 \\
0.31 \\
0.31\end{array}$ & 7.07 & 7.18 & 69.44 & 41.42 \\
\hline $7 a$ & $\begin{array}{l}\text { air } \\
\text { air } \\
\text { air }\end{array}$ & $\begin{array}{l}\text { air } \\
10 \% \mathrm{CO}_{2} \\
\text { air }\end{array}$ & $\begin{array}{l}100 \\
100 \\
100\end{array}$ & $\begin{array}{l}39 \\
48 \\
39\end{array}$ & $\begin{array}{l}4 \\
4 \\
4\end{array}$ & $\begin{array}{l}0.35 \\
0.44 \\
0.35\end{array}$ & $\begin{array}{l}7.32 \\
7.25 \\
7.24\end{array}$ & $\begin{array}{l}7.40 \\
7.13 \\
7.34\end{array}$ & $\begin{array}{l}42.13 \\
46.51 \\
46.56\end{array}$ & $\begin{array}{l}26.18 \\
60.67 \\
28.13\end{array}$ \\
\hline $7 \mathrm{~b}$ & $\begin{array}{l}\text { air } \\
10 \% \mathrm{CO}_{2} \\
\text { air }\end{array}$ & $\begin{array}{l}\text { air } \\
\text { air } \\
\text { air }\end{array}$ & $\begin{array}{l}100 \\
100 \\
100\end{array}$ & $\begin{array}{l}40 \\
40 \\
40\end{array}$ & $\begin{array}{l}4 \\
4 \\
4\end{array}$ & $\begin{array}{l}0.36 \\
0.36 \\
0.36\end{array}$ & 7.09 & 7.07 & 67.01 & 58.93 \\
\hline $8 a$ & $\begin{array}{l}\text { air } \\
\text { air } \\
\text { air }\end{array}$ & $\begin{array}{l}\text { air } \\
10 \% \mathrm{CO}_{2} \\
\text { air }\end{array}$ & $\begin{array}{l}60 \\
60 \\
60\end{array}$ & $\begin{array}{l}20 \\
24 \\
19\end{array}$ & $\begin{array}{l}7 \\
5 \\
6\end{array}$ & $\begin{array}{l}0.21 \\
0.31 \\
0.21\end{array}$ & 7.50 & $\begin{array}{l}7.39 \\
7.35 \\
7.38\end{array}$ & $\begin{array}{l}32.14 \\
32.12\end{array}$ & $\begin{array}{l}21.09 \\
30.50 \\
20.01\end{array}$ \\
\hline $8 b$ & $\begin{array}{l}\text { air } \\
10 \% \mathrm{CO}_{2} \\
\text { air }\end{array}$ & $\begin{array}{l}\text { air } \\
\text { air } \\
\text { air }\end{array}$ & $\begin{array}{l}60 \\
60 \\
60\end{array}$ & $\begin{array}{l}18 \\
17 \\
18\end{array}$ & $\begin{array}{l}4 \\
3 \\
4\end{array}$ & $\begin{array}{l}0.23 \\
0.23 \\
0.23\end{array}$ & 7.07 & 7.18 & 73.04 & 59.16 \\
\hline $9 a$ & $\begin{array}{l}\text { air } \\
\text { air } \\
\text { air }\end{array}$ & $\begin{array}{l}\text { air } \\
10 \% \mathrm{CO}_{2} \\
\text { air }\end{array}$ & $\begin{array}{l}60 \\
60 \\
60\end{array}$ & $\begin{array}{l}17 \\
23 \\
21\end{array}$ & $\begin{array}{l}4 \\
3 \\
3\end{array}$ & $\begin{array}{l}0.21 \\
0.33 \\
0.30\end{array}$ & $\begin{array}{l}7.28 \\
7.34\end{array}$ & $\begin{array}{l}7.33 \\
7.25\end{array}$ & $\begin{array}{l}36.83 \\
29.15\end{array}$ & $\begin{array}{l}25.73 \\
28.81\end{array}$ \\
\hline $9 b$ & $\begin{array}{l}\text { air } \\
10 \% \mathrm{CO}_{2} \\
\text { air }\end{array}$ & $\begin{array}{l}\text { air } \\
\text { air } \\
\text { air }\end{array}$ & $\begin{array}{l}60 \\
60 \\
60\end{array}$ & $\begin{array}{l}21 \\
18 \\
18\end{array}$ & $\begin{array}{l}5 \\
5 \\
8\end{array}$ & $\begin{array}{l}0.26 \\
0.21 \\
0.16\end{array}$ & 6.92 & 6.95 & 82.00 & 68.50 \\
\hline
\end{tabular}

* $\mathrm{PA}=$ pulmonary artery $; \mathrm{PV}=$ pulmonary vein. 


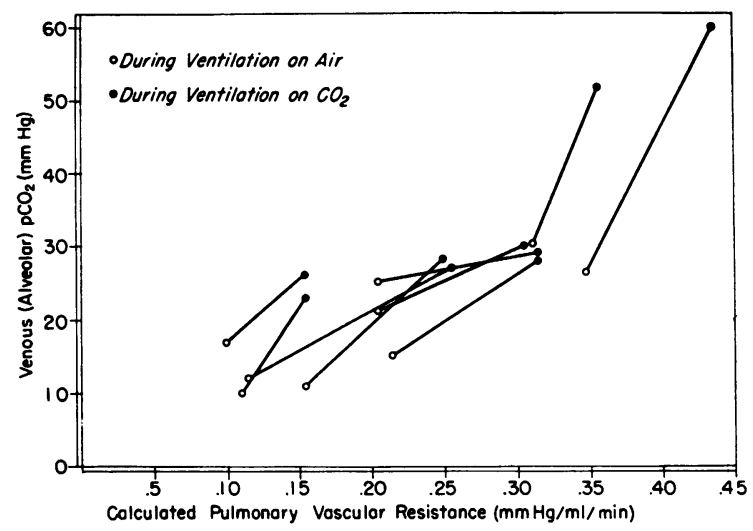

Fig. 2. Simultaneous changes in pulmonary veNous (alveolar) PCO, AND CalCulated PUlMonary VASCULAR RESISTANCE DURING VENTILATION OF LEFT LOWER LOBE WITH CARBON DIOXIDE MIXTURE.

culated pulmonary vascular resistance was observed in the isolated lobe (Figure 3 ). Moreover, perfusion with hypocapnic blood $\left(\mathrm{pCO}_{2}\right.$ of $16 \mathrm{~mm} \mathrm{Hg}$ ) produced no significant change in pulmonary arterial pressure or vascular resistance in three experiments.

The results for an individual experiment are plotted in Figure 4 and relate change in pulmonary arterial and venous carbon dioxide tension, mean

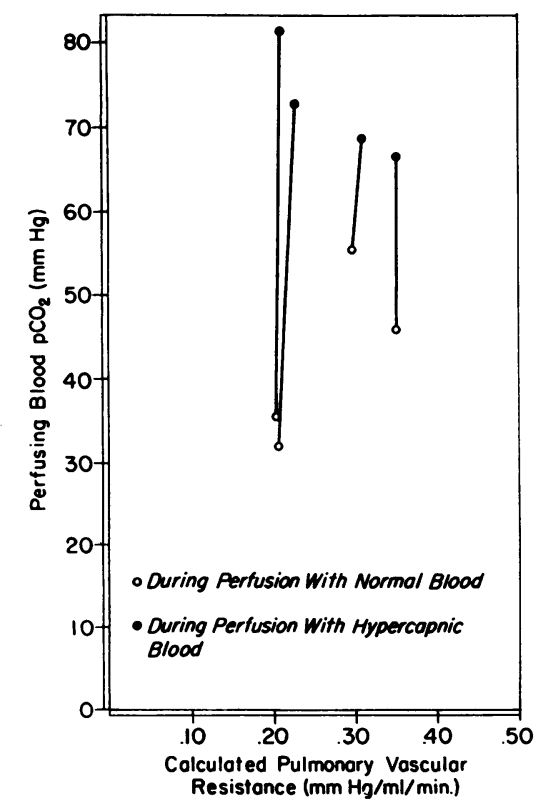

Fig. 3. Changes in Left lower lobe pulmonary aRTERY $\mathrm{PCO}_{2}$ WERE NOT ASSOCIATED WITH SIGNIFICANT VARIATIONS OF LOCAL CALCULATED PULMONARY VASCULAR RESISTANCE. arterial and venous pressures, and calculated pulmonary vascular resistance in the isolated lobe. With narrowing of the arteriovenous gradient for carbon dioxide, pulmonary arterial pressure and calculated pulmonary vascular resistance increased. Although the carbon dioxide tension of the perfusing blood was markedly elevated in the second phase of the experiment, a normal arteriovenous gradient for carbon dioxide was maintained, and no change in pulmonary hemodynamics was observed.

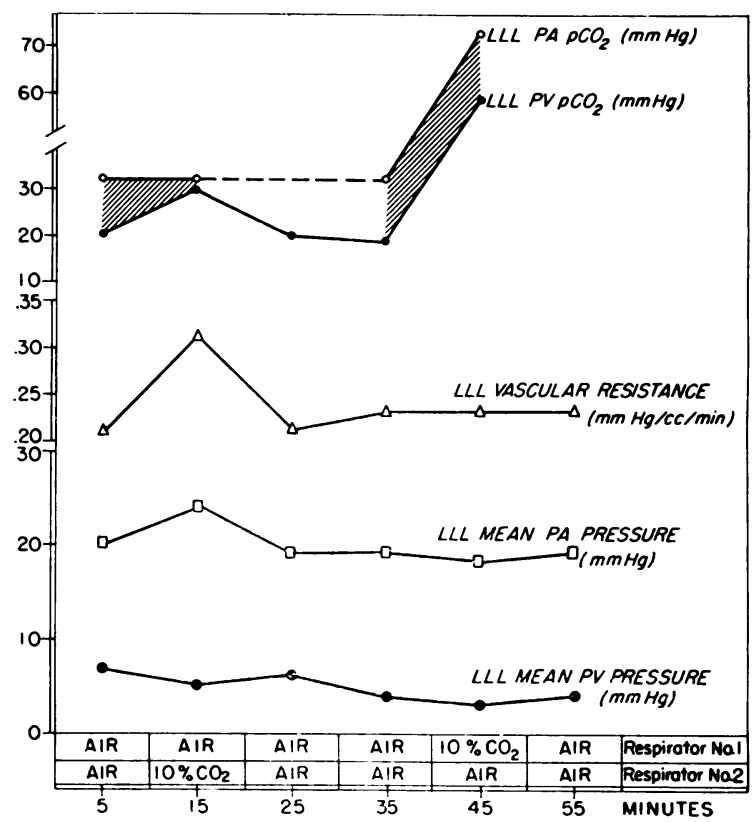

Fig. 4. EXAMple of an individual experiment (SEE $\mathrm{TEXT}$ ). LLL = left lower lobe; PA = pulmonary artery ; $\mathrm{PV}=$ pulmonary vein.

In Figure 5 the changes in pulmonary arteriovenous carbon dioxide tension gradient are plotted against calculated pulmonary vascular resistance for seven experiments. As the arteriovenous difference for carbon dioxide narrowed, calculated pulmonary vascular resistance increased.

In three animals, ventilation of the left lower lobe with low oxygen mixtures (13 to 16 per cent) resulted in a mean change in pulmonary venous oxygen saturation from 94.0 to 79.0 per cent. Mean increases were observed in pulmonary arterial pressure and calculated pulmonary vascular resistance from 19 to $24 \mathrm{~mm} \mathrm{Hg}$ and from 0.33 to $0.37 \mathrm{~mm} \mathrm{Hg}$ per $\mathrm{ml}$ per minute, respectively. Perfusion of the lobe with hypoxic blood (oxygen 
saturation of 20 per cent) produced no change in the calculated pulmonary vascular resistance.

\section{DISCUSSION}

In the isolated lung lobe used for these studies, all the factors capable of producing circulatory changes, such as blood flow, airway resistance, and left heart hemodynamics, were controlled. Therefore, variations in the calculated pulmonary vascular resistance were taken as expression of pulmonary vasomotor activity. Moreover, in the technique of isolating the lobe, most of its nervous supply was resected and the hemodynamic alterations observed were interpreted as reflecting a local rather than a central response to change in alveolar gas tensions. The data presented indicate that the partial pressure of carbon dioxide, as well as of oxygen, at the level of the alveolus has a role in regulating the alveolar perfusion.

Simultaneous changes of either carbon dioxide or oxygen tension in the pulmonary artery and in the pulmonary vein of the isolated lobe had no effect on local hemodynamics. On the other hand, an increase in alveolar and venous $\mathrm{pCO}_{2}$, whereby the gradient for $\mathrm{pCO}_{2}$ between the blood reaching the alveolus and the blood leaving the alveolus is lowered, produces a local elevation of the calculated pulmonary vascular resistance. This is exemplified by the schematic drawing shown in Figure 6 . The sections on the right in each of the three drawings indicate the explored pulmonary segment, namely the left lower lobe. Drawing 1 represents the baseline situation when the pulmonary arteriovenous gradient in the explored lobe for one of the respiratory gases, in this case carbon dioxide, is $11 \mathrm{~mm} \mathrm{Hg}$. After administration of carbon dioxide to the left lower lobe, the gradient decreases to $1 \mathrm{~mm} \mathrm{Hg}$, and local vascular constriction ensues (Drawing 2). After administration of carbon dioxide to the remaining lobes of the lungs, the $\mathrm{pCO}_{2}$ in the perfusing blood increases markedly, but the gradient remains wide and no vasomotor response is detected (Drawing 3).

Apparently a decrease in gradient of carbon dioxide or oxygen tension across the alveolus is capable of regulating local resistance and pressure levels. The site of action of this vasomotor response has not been definitely identified. Pulmonary arteriolar constriction has been suggested

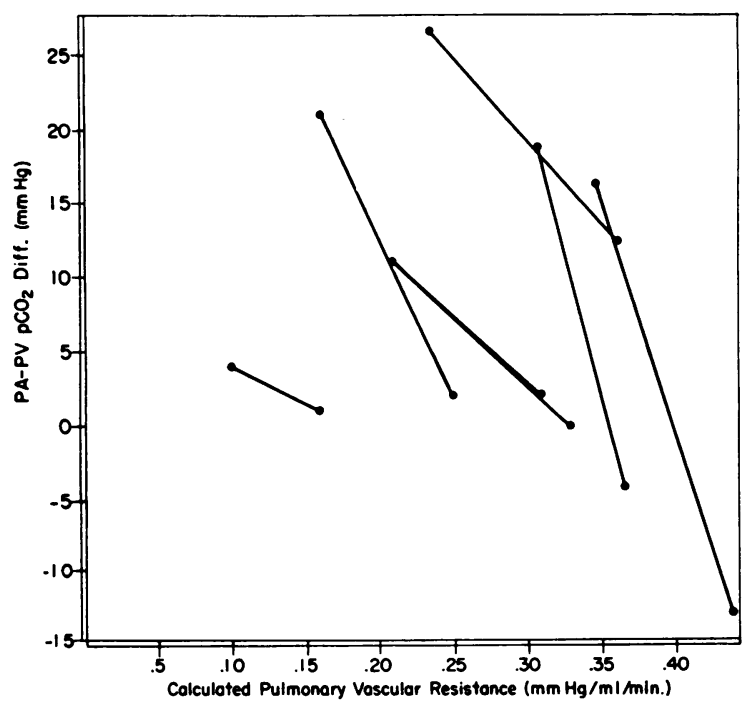

Fig. 5. Simultaneous changes in pulmonary arTERIOVENOUS $\mathrm{PCO}_{2}$ GRAdIENT AND CALCULATED PULMONARY VASCULAR RESISTANCE IN THE ISOLATED LEFT LOWER LOBE. $\mathrm{PA}=$ pulmonary artery; $\mathrm{PV}=$ pulmonary vein.

by von Euler and Liljestrand (1), Siebens, Smith and Storey (7), Rahn and Bahnson (20), Hürlimann and Wiggers (21), and Stroud and Conn (22). It has also been proposed that the vasomotor activity of the alveolar capillaries could be responsible for the hemodynamic changes that follow alterations in alveolar oxygen tension (4). Finally, there is suggestive evidence that the pulmonary veins may play an important role in this vasomotor reaction $(10,23)$. With the use

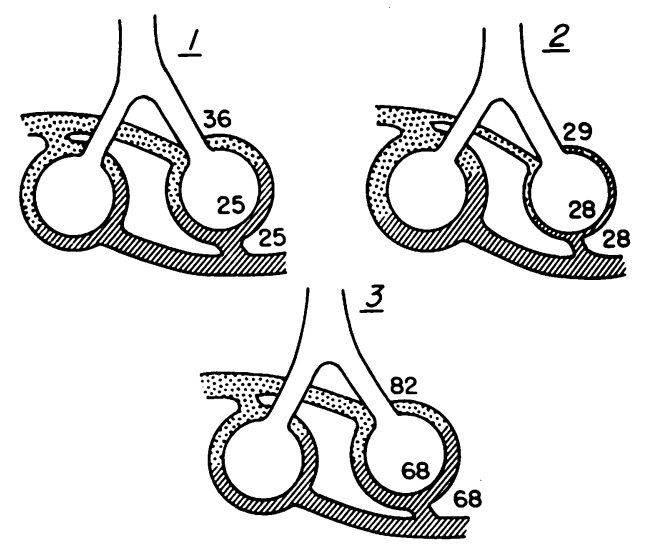

Fig. 6. Diagrammatic PREsentation of EFfect of CARBON DIOXIDE ON PULMONARY VASCULAR RESISTANCE. Values represent carbon dioxide tension in millimeters of $\mathrm{Hg}$; dotted areas, pulmonary arterioles; lined areas, pulmonary venules (see text). 
of Knisely's technique (24) for direct visualization of small pulmonary vessels, the problem of identifying the vascular segment responsible for the increase in resistance to blood flow through hypoxic and hypercapnic areas of the lung is being investigated in our laboratory. Preliminary observations on dogs indicate that, when the animals are ventilated with high concentrations of carbon dioxide, a measurable decrease in diameter occurs (mean decreases ranged from 4 to 21 per cent) at the level of the pulmonary arterioles (100 to $200 \mu$ ), which return to their previous size when air breathing is resumed (25).

From our experiments the possible role, if any, played by the vascular anastomotic systems within the lungs (bronchial artery-pulmonary artery ; pulmonary artery-pulmonary vein; pulmonary veinbronchopulmonary vein) in producing pulmonary hemodynamic alterations, cannot be ascertained.

No correlation has been found between variations in the pulmonary arterial and venous blood $\mathrm{pH}$, as measured directly, and pulmonary dynamic changes. Therefore, it can be stated that the $\mathrm{pH}$ changes, whenever they occur, are not of primary importance in regulating the vascular responsiveness.

Investigations by other workers, and observations made by us as a corollary study to the carbon dioxide experiments, have shown that a decrease in alveolar oxygen tension results in elevation of the pulmonary vascular resistance. It would appear that whenever oxygen uptake across the alveolus is for any reason decreased, a local increase in the resistance to flow of blood ensues. The results of the present study indicate that a similar phenomenon may occur when alveolar function is impaired and there is alveolar carbon dioxide retention with consequent decrease in the local arteriovenous $\mathrm{pCO}_{2}$ gradient. It is suggested that under these circumstances, arteriolar vasoconstriction takes place in the attempt to divert blood to well ventilated segments of the lungs. Moreover, it is also possible that when rapid carbon dioxide retention occurs in large areas of the lungs, as in acute and diffuse pulmonary diseases, widespread increased resistance to flow may be significant in producing pulmonary hypertension and right-sided failure, along with factors such as hypoxia and increased cardiac output.

\section{SUMMARY}

The effect of alveolar and blood carbon dioxide tension changes on the pulmonary vascular dynamics has been studied in 12 dogs, using the left lower lobe isolated and mechanically ventilated and perfused. Corollary observations have also been made for alveolar and blood oxygen tension changes. Increase in alveolar and pulmonary venous carbon dioxide tension, whereby the $\mathrm{pCO}_{2}$ gradient between pulmonary arterial and pulmonary venous blood was lowered, resulted in a local elevation of pulmonary vascular resistance, probably from pulmonary arteriolar constriction. No significant hemodynamic variation occurred with high or low carbon dioxide tensions in the pulmonary artery, vein, or alveoli of the explored lung segment as long as a large pulmonary arteriovenous gradient for $\mathrm{pCO}_{2}$ was maintained.

Decrease in alveolar and pulmonary venous oxygen tension, whereby the oxygen tension gradient between pulmonary arterial and venous blood was lowered, resulted also in local elevation of pulmonary vascular resistance. Perfusion of the isolated lobe with hypoxic blood produced no change in local pulmonary vascular resistance.

It is postulated that a local homeostatic mechanism exists, probably similar to the one described for oxygen, which can divert blood from poorly ventilated alveoli that retain carbon dioxide to adequately ventilated segments of the lung.

\section{REFERENCES}

1. von Euler, U. S., and Liljestrand, G. Observations on pulmonary arterial blood pressure in cat. Acta physiol. scand. 1946, 12, 301.

2. Atwell, R. J., Hickam, J. B., Pryor, W. W., and Page, E. B. Reduction of blood flow through hypoxic lung. Amer. J. Physiol. 1951, 166, 37.

3. Stroud, R. C., and Conn, H. L., Jr. Pulmonary vascular effects of moderate and severe hypoxia in the dog. Amer. J. Physiol. 1954, 179, 119.

4. Duke, H. N. The site of action of anoxia on the pulmonary blood vessels of the cat. J. Physiol. $1954,125,373$.

5. Westcott, R. N., Fowler, N. O., Scott, R. C., Hauenstein, V. D., and McGuire, J. Anoxia and human pulmonary vascular resistance. J. clin. Invest. 1951, 30, 957.

6. Doyle, J. T., Wilson, J. S., and Warren, J. V. The pulmonary vascular responses to short-term hypoxia in human subjects. Circulation 1952, 5, 263. 
7. Siebens, A. A., Smith, R. E., and Storey, C. F. Effect of hypoxia on pulmonary vessels in man. Amer. J. Physiol. 1955, 180, 428.

8. Daley, R. The autonomic nervous system in its relation to some forms of heart and lung disease. II. Lung disease. Brit. med. J. 1957, 2, 249.

9. Nisell, O. I. The action of oxygen and carbon dioxide on the bronchioles and vessels of the isolated perfused lungs. Acta physiol. scand. (Suppl. 73) 1950, 21, 1.

10. Nisell, O. Reactions of the pulmonary venules of the cat with special reference to the effect of the pulmonary elastance. Acta physiol. scand. 1951, 23, 361.

11. Stroud, R. C., and Rahn, H. Effect of $\mathrm{O}_{2}$ and $\mathrm{CO}_{2}$ tensions upon the resistance of pulmonary blood vessels. Amer. J. Physiol. 1953, 172, 211.

12. Weil, P., Salisbury, P. F., and State, D. Physiological factors influencing pulmonary artery pressure during separate perfusion of the systemic and pulmonary circulations in the dog. Amer. J. Physiol. 1957, 191, 453.

13. Borst, H. G., Whittenberger, J. L., Berglund, E., and McGregor, M. Effects of unilateral hypoxia and hypercapnia on pulmonary blood flow distribution in the dog. Amer. J. Physiol. 1957, 191, 446.

14. Shephard, R. J. The effect of carbon dioxide on the pulmonary circulation in congenital heart disease. Brit. Heart J. 1954, 16, 451.

15. Peters, R. M. Effect of unilateral carbon dioxide breathing on pulmonary blood flow. Amer. J. Physiol. 1957, 191, 399.
16. Hickam, J. B., and Frayser, R. Spectrophotometric determination of blood oxygen. J. biol. Chem. 1949, 180, 457.

17. Peters, J. P., and Van Slyke, D. D. Quantitative Clinical Chemistry. Methods. Baltimore, Williams and Wilkins, 1932, vol. II.

18. Rosenthal, T. B. Effect of temperature on $\mathrm{pH}$ of blood and plasma in vitro. J. biol. Chem. 1948, 173, 25.

19. Van Slyke, D. D., and Sendroy, J., Jr. Studies of gas and electrolyte equilibria in blood; line charts for graphic calculations by Henderson-Hasselbalch equation, and for calculating plasma carbon dioxide content from whole blood content. J. biol. Chem. 1928, 79, 781.

20. Rahn, H., and Bahnson, H. T. Effect of unilateral hypoxia on gas exchange and calculated pulmonary blood flow in each lung. J. appl. Physiol. 1953, 6, 105.

21. Hürlimann, A., and Wiggers, C. J. The effects of progressive general anoxia on the pulmonary circulation. Circulat. Res. 1953, 1, 230.

22. Stroud, R. C., and Conn, H. L., Jr. Pulmonary vascular effects of moderate and severe hypoxia in the dog. Amer. J. Physiol. 1954, 179, 119.

23. Rivera-Estrada, C., Saltzman, P. W., Singer, D., and Katz, L. N. Action of hypoxia on the pulmonary vasculature. Circulat. Res. 1958, 6, 10.

24. Knisely, M. H. The fused quartz rod technique for transilluminating living internal organs in situ for microscopic study. Anat. Rec. 1954, 120, 265.

25. Manfredi, F., and Frayser, R. Unpublished observations. 